(c) American Dairy Science Association, 2005.

\title{
Effects of Estradiol on Bovine Thecal Cell Function In Vitro: Dependence on Insulin and Gonadotropins*
}

\author{
L. J. Spicer \\ Department of Animal Science, Oklahoma State University, Stillwater 74078
}

\begin{abstract}
The objective of this study was to evaluate the influence of estradiol (E2) on proliferation and steroid production by thecal cells obtained from large $(\geq 8 \mathrm{~mm})$ follicles of cattle. Five experiments evaluated the effect of various doses of E2 during a 2-d exposure in serumfree medium on hormone-induced steroidogenesis and cell proliferation. In LH-treated thecal cells of experiment 1, $300 \mathrm{ng} / \mathrm{mL}$ of E2 decreased progesterone production by $30 \%$ and increased androstenedione production to 5.8-fold of controls. In the absence of LH, both 3 and $300 \mathrm{ng} / \mathrm{mL}$ of $\mathrm{E} 2$ increased progesterone production. In experiment 2 , in the presence of insulin and $\mathrm{LH}, 3,30$, and $300 \mathrm{ng} / \mathrm{mL}$ of $\mathrm{E} 2$ decreased progesterone production (by 17 to $36 \%$ ), whereas $3 \mathrm{ng} / \mathrm{mL}$ of $\mathrm{E} 2$ decreased and $300 \mathrm{ng} / \mathrm{mL}$ of E2 increased androstenedione production. Doses of $\mathrm{LH}$ ( 3 to $30 \mathrm{ng} / \mathrm{mL}$ ) tested in experiment 3 increased (to as much as 3.7 -fold) progesterone production by thecal cells and E2 attenuated this stimulatory effect by $40 \%$. In contrast, E2 amplified the stimulatory effect of $\mathrm{LH}$ on androstenedione production in experiment 3 . In experiment 4 , E2 $(300 \mathrm{ng} / \mathrm{mL})$ decreased IGF-I- and insulin-induced thecal cell progesterone production by 70 to $77 \%$, whereas E2 increased basal, IGF-I, and insulin-induced androstenedione production. In experiment 5, in the presence of insulin, 10 to $1000 \mathrm{ng} / \mathrm{mL}$ of E2 had no effect on [ $\left.{ }^{125} \mathrm{I}\right]$-IGF-I binding to thecal cells, whereas 10 and $100 \mathrm{ng} / \mathrm{mL}$ of $\mathrm{E} 2$ increased and $1000 \mathrm{ng} / \mathrm{mL}$ of $\mathrm{E} 2$ decreased progesterone production by thecal cells. Estradiol had no consistent effect on thecal cell numbers among the 5 experiments. These results support the hypothesis that E2 may act as a paracrine factor to directly regulate hormone-induced steroid production by thecal cells without affecting cell numbers or numbers of insulin-like growth factor type I receptors.
\end{abstract}

\footnotetext{
Received December 1, 2004.

Accepted March 17, 2005.

E-mail: igf1Leo@okstate.edu.

*This work was approved for publication by the Director, Oklahoma Agricultural Experiment Station, and supported in part under projects $\mathrm{H}-2329$ and $\mathrm{H}-2510$.
}

(Key words: estradiol, thecal cell, insulin-like growth factor, steroidogenesis)

\begin{abstract}
Abbreviation key: E2 = estradiol, ER = estrogen receptor, FCS $=$ fetal calf serum, hCG = human chorionic gonadotropin.
\end{abstract}

\section{INTRODUCTION}

During preovulatory follicular growth, increases in systemic concentrations of estradiol (E2) in cattle influence a variety of functions including stimulation of estrous behavior, ovulatory gonadotropin surges, and gamete transport (Spicer and Echternkamp, 1986; Buhi, 2002; Orikasa and Sakuma, 2003). In lactating dairy cows, plasma and follicular fluid estradiol concentrations are negatively correlated with daily milk yield (Beam and Butler, 1998) and are reduced by high environmental temperatures (Wolfenson et al., 1997; Wilson et al., 1998). Because these factors have been associated with reduced reproductive efficiency, an association between reduced concentrations of estradiol and decreased reproductive efficiency is plausible. Direct effects of estradiol on ovarian cell function were first reported in cattle in 1979 (Fortune and Hansel, 1979a,b), and shown to be important modulators of FSH action in granulosa cells of rats (Richards et al., 1976; Tonetta et al., 1985) and pigs (Veldhuis et al., 1982; 1984). However, the effect of estradiol on thecal cell function has not been well described. Estrogen receptors (ER) and their mRNA ( $\alpha$ and $\beta$ ) have been detected in bovine (Rosenfeld et al., 1999; Bao et al., 2000; Berisha et al., 2002; Van Den Broeck et al., 2002), porcine (Slomczynska and Wozniak, 2001), and human (Brandenberger et al., 1998; Sharma et al., 1999; Jakimiuk et al., 2002) granulosa and thecal cells. Furthermore, E2 directly alters ovarian granulosa cell steroidogenesis in several species, and $\operatorname{ER} \alpha$ knockout female mice are unable to ovulate in response to exogenous gonadotropins (Couse et al., 1999). Specifically, Fortune and Hansel (1979a) and Langhout et al. (1991) found that E2 inhibited progesterone production by bovine granulosa cells in the presence of fetal calf serum (FCS) and insulin, respectively. Hunter and Armstrong (1987) and Gilling-Smith et al. (1997) found that E2 inhibited basal 
and LH-induced progesterone production by porcine and human thecal cells, respectively. Voge et al. (2004) found that E2 decreased IGF binding protein-2, -3, and -4 mRNA levels in bovine thecal cells. However, the effect of E2 on hormone-induced steroidogenesis of ovarian thecal cells in cattle has not been thoroughly evaluated. Therefore, the objective of the present study was to examine the effects of estradiol on basal and hormoneinduced steroidogenesis of thecal cells from bovine ovarian follicles.

\section{MATERIALS AND METHODS}

\section{Reagents and Hormones}

Reagents were Dulbecco's modified Eagle medium, Ham's F12 medium, insulin (bovine; $28 \mathrm{U} / \mathrm{mg}$ ), pronase $\mathrm{E}$, collagenase, hyaluronidase, DNase, FCS, and E2 obtained from Sigma Chemical Co. (St. Louis, MO); bovine LH (L1913; LH activity $2 \times$ NIH-LH-S1 U/mg) obtained from Scripps Laboratories (San Diego, CA); and recombinant human IGF-I obtained from R\&D Systems (Minneapolis, MN).

\section{Cell Culture}

Ovaries were obtained at a nearby commercial abattoir from beef and dairy cattle after slaughter. The ovaries were transported to the laboratory $(<120 \mathrm{~min})$ and processed as described previously (Langhout et al., 1991; Stewart et al., 1995; Spicer et al., 2001a). Thecal cells from large ( 8 to $22 \mathrm{~mm}$ ) follicles were isolated via enzyme digestion as previously described (Stewart et al., 1995; Spicer and Stewart, 1996a; Spicer and Chamberlain, 1998). The purity of thecal cells prepared this way has been estimated at $>95 \%$ (Roberts and Skinner, 1990a,b; Spicer and Stewart, 1996a). Isolated cells were resuspended in medium containing $1.25 \mathrm{mg} / \mathrm{mL}$ of collagenase and $0.5 \mathrm{mg} / \mathrm{mL}$ of DNase to prevent clumping of the cells. Basal medium consisted of a 1:1 mixture of Dulbecco's modified Eagle medium and Ham's F-12 containing $0.12 \mathrm{~m} M$ gentamicin, $2.0 \mathrm{~m} M$ glutamine, and $38.5 \mathrm{~m} M$ sodium bicarbonate. Viable cells were then determined by the trypan blue exclusion method; viability averaged $92 \pm 1 \%$ for thecal cells. Approximately $2 \times 10^{5}$ viable cells were placed in each well of Falcon 24-well plates (no. 3047, Becton Dickinson, Lincoln Park, NJ) containing $1 \mathrm{~mL}$ of medium. Cells were cultured at $38.5^{\circ} \mathrm{C}$ in a $95 \%$ air $/ 5 \% \mathrm{CO}_{2}$ atmosphere, and the medium was changed every $24 \mathrm{~h}$. Thecal cells grown in this culture system establish monolayers and retain hormonally responsive androstenedione and progesterone production (Stewart et al., 1995; Spicer and Stewart, 1996a; Spicer and Chamberlain, 1998).
Experiment 1 was conducted to determine the effect of 0,3 , or $300 \mathrm{ng} / \mathrm{mL}$ of $\mathrm{E} 2$ on thecal cell steroidogenesis in the absence of growth factors. Thecal cells from large ( $\geq 8 \mathrm{~mm}$ ) follicles were cultured for $2 \mathrm{~d}$ in medium containing $10 \% \mathrm{FCS}$ and then cultured in serum-free medium for an additional $2 \mathrm{~d}$ with $\mathrm{LH}(0$ or $30 \mathrm{ng} / \mathrm{mL}$ ) and E2 $(0,3$, or $300 \mathrm{ng} / \mathrm{mL})$. Medium was changed every 24 h. The doses of E2 were selected to represent typical average values within the wide range of concentrations of E2 in follicular fluid of dairy (Stewart et al., 1996; Spicer et al., 2001b) and beef (Spicer et al., 1986a,b, 1987) cows.

Experiment 2 was conducted to evaluate the effect of 0, 30, or $300 \mathrm{ng} / \mathrm{mL}$ of $\mathrm{E} 2$ on thecal cell steroidogenesis in the presence of LH and insulin. Thecal cells were cultured as in experiment 1 except that, during the last $2 \mathrm{~d}$ of culture, E2 $(0,30$, or $300 \mathrm{ng} / \mathrm{mL}), \mathrm{LH}(30 \mathrm{ng} / \mathrm{mL})$, and insulin $(100 \mathrm{ng} / \mathrm{mL})$ were added to the medium. The doses of E2 were selected as per experiment 1, and doses of LH and insulin were selected based on previous studies (Stewart et al., 1995; Spicer and Stewart, 1996a,b; Spicer and Chamberlain, 1998).

Experiment 3 was conducted to evaluate the effect of E2 on thecal cell steroid production in the presence of insulin and either low or high doses of LH. Thecal cells from large $(\geq 8 \mathrm{~mm})$ follicles were cultured for $2 \mathrm{~d}$ in medium containing $10 \%$ FCS and then cultured in serum-free medium for an additional $2 \mathrm{~d}$ with insulin (1000 ng/mL), LH (0, 3, or $30 \mathrm{ng} / \mathrm{mL})$, and E2 (0 or 300 $\mathrm{ng} / \mathrm{mL}$ ). Medium was changed every $24 \mathrm{~h}$. The doses of $\mathrm{E} 2, \mathrm{LH}$, and insulin were selected based on experiments 1 and 2.

Experiment 4 was designed to compare the effect of E2 on basal, IGF-I, and insulin-induced thecal cell steroidogenesis. Thecal cells from large $(\geq 8 \mathrm{~mm})$ follicles were cultured for $2 \mathrm{~d}$ in medium containing $10 \%$ FCS and then cultured in serum-free medium for an additional $2 \mathrm{~d}$ with $\mathrm{LH}(30 \mathrm{ng} / \mathrm{mL})$ and IGF-I (0 or $30 \mathrm{ng} /$ $\mathrm{mL}$ ) or insulin (0 or $100 \mathrm{ng} / \mathrm{mL}$ ). During the last $2 \mathrm{~d}$ of culture, E2 (0 or $300 \mathrm{ng} / \mathrm{mL})$ was added to the medium. Medium was changed every $24 \mathrm{~h}$. Doses of E2, LH, insulin, and IGF-I were selected based on experiments 1 and 2.

Experiment 5 was conducted to evaluate the effect of $0,10,100$, or $1000 \mathrm{ng} / \mathrm{mL}$ of $\mathrm{E} 2$ on thecal IGF-I receptors and steroidogenesis. Thecal cells from large follicles $(\geq 8$ $\mathrm{mm}$ ) were cultured for $2 \mathrm{~d}$ in medium containing $10 \%$ FCS and then cultured in serum-free medium for an additional $2 \mathrm{~d}$ with insulin $(10 \mathrm{ng} / \mathrm{mL})$ and $\mathrm{E} 2(0,10$, 100 , or $1000 \mathrm{ng} / \mathrm{mL}$ ). Medium was changed every $24 \mathrm{~h}$. The doses of E2 and insulin were selected based on experiments 1 and 2 . Because $\mathrm{E} 2$ was dissolved in ethanol, all treatments without E2 received the same vol- 
ume of ethanol (final ethanol content $=0.003 \%$ ) as a vehicle control for all experiments.

\section{Determination of Cell Number}

Medium was collected from individual wells and frozen at $-20^{\circ} \mathrm{C}$ for subsequent hormone analyses. Cells were gently washed twice with $0.9 \%$ saline $(500 \mu \mathrm{L})$, exposed to $500 \mu \mathrm{L}$ of trypsin solution $(0.25 \% \mathrm{wt} / \mathrm{vol})$ for $20 \mathrm{~min}$ at $25^{\circ} \mathrm{C}$, and then scraped from each well. Cell aggregates were disrupted by pipetting the cell suspension back and forth through a $500-\mu \mathrm{L}$ pipette tip 3 to 5 times, and cells were then diluted in $9 \mathrm{~mL}$ of $0.9 \%$ saline, and counted using a Coulter counter (model Zm; Coulter Electronics, Hialeah, FL) as previously described (Langhout et al., 1991; Stewart et al., 1995).

\section{Assays}

Concentrations of progesterone and androstenedione in culture medium were determined by radioimmunoassays as previously described (Langhout et al., 1991; Stewart et al., 1995; Spicer et al., 1996). The intra- and interassay coefficients of variation were 10 and $16 \%$ for progesterone radioimmunoassay and 7 and $13 \%$ for the androstenedione assay. Because $\mathrm{E} 2$ cross-reacted in the androstenedione assay, unspent medium samples were assayed and these values were subtracted from E2treated samples values.

Numbers of binding sites for $\left[{ }^{125} \mathrm{I}\right]-\mathrm{IGF}-\mathrm{I}$ in bovine thecal cells were determined as previously described (Stewart et al., 1995; Spicer and Stewart, 1996b; Spicer, 2001). Briefly, numbers of specific [ $\left.{ }^{125} \mathrm{I}\right]-\mathrm{IGF}-\mathrm{I}$ binding sites were determined by incubating cells with a saturating amount (approximately $250,000 \mathrm{cpm}$ ) of $\left[{ }^{125} \mathrm{I}\right]-$ IGF-I for $16 \mathrm{~h}$ at $4^{\circ} \mathrm{C}$ in the $17-\mathrm{mm}$ wells of the multiwell culture plate. Nonspecific binding was measured in the presence of $500 \mathrm{ng}$ of unlabeled IGF-I. After the 16$\mathrm{h}$ incubation, wells were washed, and the cells were solubilized with $1 \mathrm{~N} \mathrm{NaOH}$ and counted in a gamma counter (counter efficiency $=75 \%$ ).

\section{Statistical Analyses}

Each experiment contained 3 replicates per treatment and each experiment was replicated 3 to 4 times with different pools of thecal cells. Each pool of thecal cells was obtained from 4 to 8 follicles collected from 3 to 6 animals. Data are presented as the least squares means $( \pm \mathrm{SE}$ ) of measurements from 9 to 12 culture wells. Main effects (i.e., hormone, dose, experimental replicate) and interactions were assessed using the GLM procedure of SAS (SAS Institute, 1999). Steroid production was expressed as nanograms or picograms per $10^{5}$ cells per $24 \mathrm{~h}$, and cell numbers at the termination of the experiment were used for this calculation. Specific differences in cell numbers, steroid production, and $\left[{ }^{125} \mathrm{I}\right]-\mathrm{IGF}-\mathrm{I}$ binding among treatments were determined using Fisher's protected least significant difference procedure (Ott, 1977).

\section{RESULTS}

\section{Experiment 1}

Progesterone production. Luteinizing hormone alone increased $(P<0.001)$ progesterone production (to 3 -fold of controls) by thecal cells, and $300 \mathrm{ng} / \mathrm{mL}$ of E2 (but not $3 \mathrm{ng} / \mathrm{mL})$ inhibited $(P<0.05)$ this increase by $30 \%$ (Figure 1A). In the absence of LH, E2 increased $(P<0.05)$ basal progesterone production to 1.4 - to 1.7fold of controls (Figure 1A).

Androstenedione production. Luteinizing hormone alone increased $(P<0.01)$ androstenedione production (to 2.5-fold of controls) by thecal cells, and 3 and $300 \mathrm{ng} / \mathrm{mL}$ of $\mathrm{E} 2$ amplified $(P<0.05)$ this increase (Figure 1B). In the absence of $\mathrm{LH}, 300 \mathrm{ng} / \mathrm{mL}$ of E2 (but not $3 \mathrm{ng} / \mathrm{mL})$ increased $(P<0.05)$ basal androstenedione production to 11-fold of controls; in the presence of $\mathrm{LH}$, this increase was to 5.8-fold of controls (Figure 1B).

Cell numbers. In contrast to steroid production, neither dose of E2 nor LH had an effect $(P>0.10)$ on cell numbers, which averaged $1.01 \pm 0.05 \times 10^{5}$ cell per well (data not shown).

\section{Experiment 2}

Progesterone production. Both E2 $(P<0.05)$ and insulin $(P<0.001)$ affected progesterone production (Figure 2A). In the presence of insulin plus LH, 3, 30, and $300 \mathrm{ng} / \mathrm{mL}$ of $\mathrm{E} 2$ decreased $(P<0.05)$ progesterone production by 17 to $36 \%$ (Figure $2 \mathrm{~A}$ ); in the absence of insulin but in the presence of $\mathrm{LH}, 300 \mathrm{ng} / \mathrm{mL}$ of $\mathrm{E} 2 \mathrm{had}$ no effect $(P>0.10)$ on progesterone production. In the absence of $\mathrm{E} 2,100 \mathrm{ng} / \mathrm{mL}$ of insulin increased $(P<0.05)$ progesterone production to 3.5 -fold of controls (Figure 2A).

Androstenedione production. In the presence of insulin plus LH, $3 \mathrm{ng} / \mathrm{mL}$ of $\mathrm{E} 2$ decreased $(P<0.05)$, $30 \mathrm{ng} / \mathrm{mL}$ of $\mathrm{E} 2$ had no effect $(P>0.10)$, and $300 \mathrm{ng} / \mathrm{mL}$ of E2 increased $(P<0.05)$ androstenedione production (Figure 2B). In the absence of insulin but presence of $\mathrm{LH}, 300 \mathrm{ng} / \mathrm{mL}$ of E2 increased $(P<0.05)$ androstenedione production to 3.8 -fold of controls (Figure $2 \mathrm{~B}$ ). In the absence of E2, $100 \mathrm{ng} / \mathrm{mL}$ of insulin amplified $(P<$ $0.05) \mathrm{LH}$-induced androstenedione production to 5.7fold of controls (Figure 2B).

Cell numbers. Doses of 3 and $30 \mathrm{ng} / \mathrm{mL}$ of $\mathrm{E} 2 \mathrm{had}$ no effect $(P>0.10)$ on cell numbers, whereas $300 \mathrm{ng} /$ 

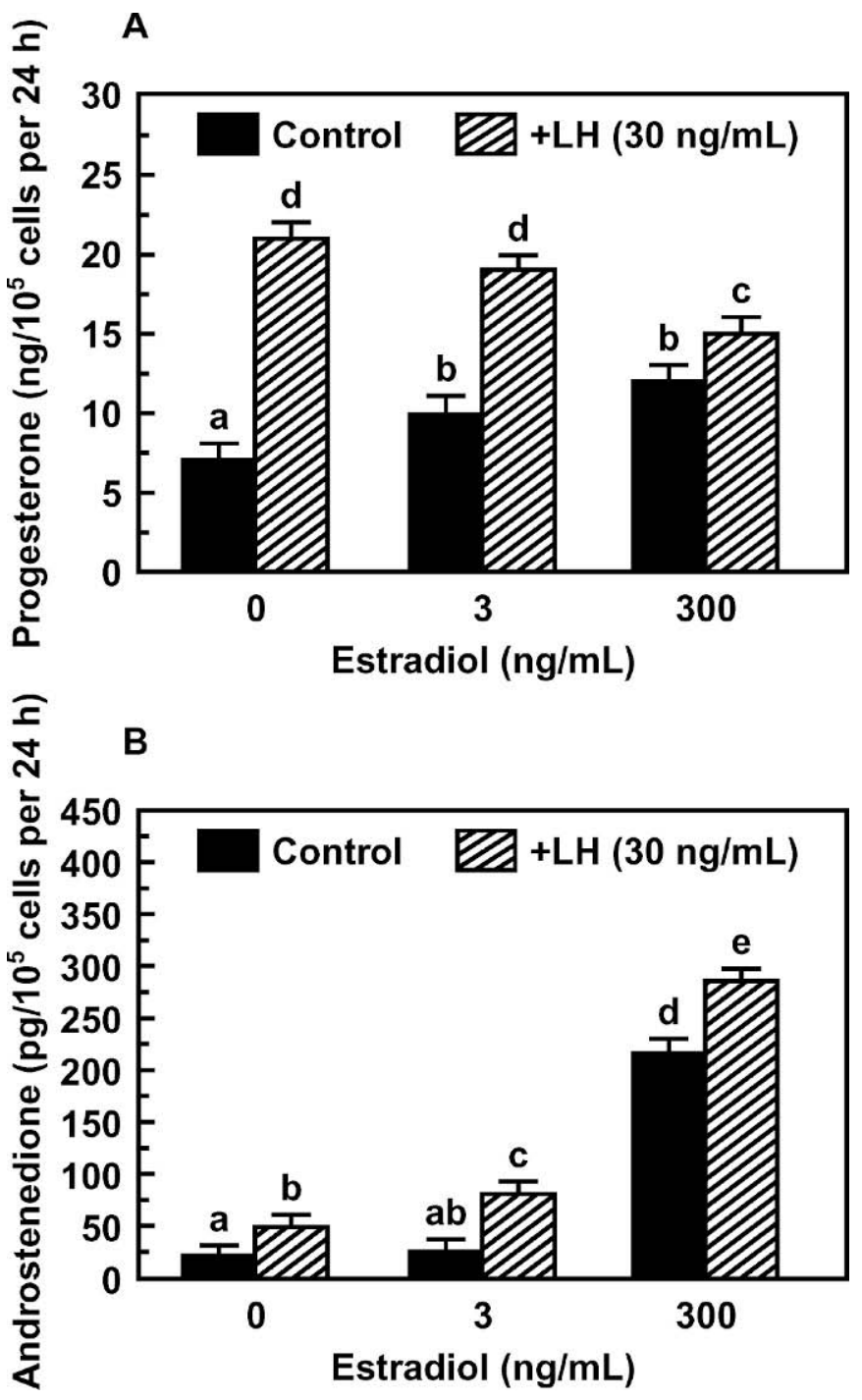

Figure 1. Effect of estradiol (E2) on basal and LH-induced progesterone (panel A) and androstenedione (panel B) production by thecal cells from large follicles (experiment 1). Thecal cells were cultured for $4 \mathrm{~d}$ as described in Materials and Methods. During the last $2 \mathrm{~d}$ of culture, cells were treated in serum-free medium with 0 or $30 \mathrm{ng} /$ $\mathrm{mL}$ of $\mathrm{LH}$ with or without various doses of E2. Values are means from 4 separate experiments. ${ }^{\mathrm{a}, \mathrm{b}, \mathrm{c}, \mathrm{d}, \mathrm{e}}$ Within a panel, means without a common letter differ $(P<0.05)$.

$\mathrm{mL}$ of $\mathrm{E} 2$ weakly increased (i.e., $9 \%$ increase) cell numbers in the presence but not absence of $100 \mathrm{ng} / \mathrm{mL}$ of insulin (Table 1).

\section{Experiment 3}

Progesterone production. In the presence of insulin $(1000 \mathrm{ng} / \mathrm{mL}), 3$ and $30 \mathrm{ng} / \mathrm{mL}$ of $\mathrm{LH}$ increased $(P$ $<0.05$ ) progesterone production to 3.0- and 3.7-fold of controls, respectively (Figure 3A). However, E2 attenuated $(P<0.05)$ this LH-induced progesterone production
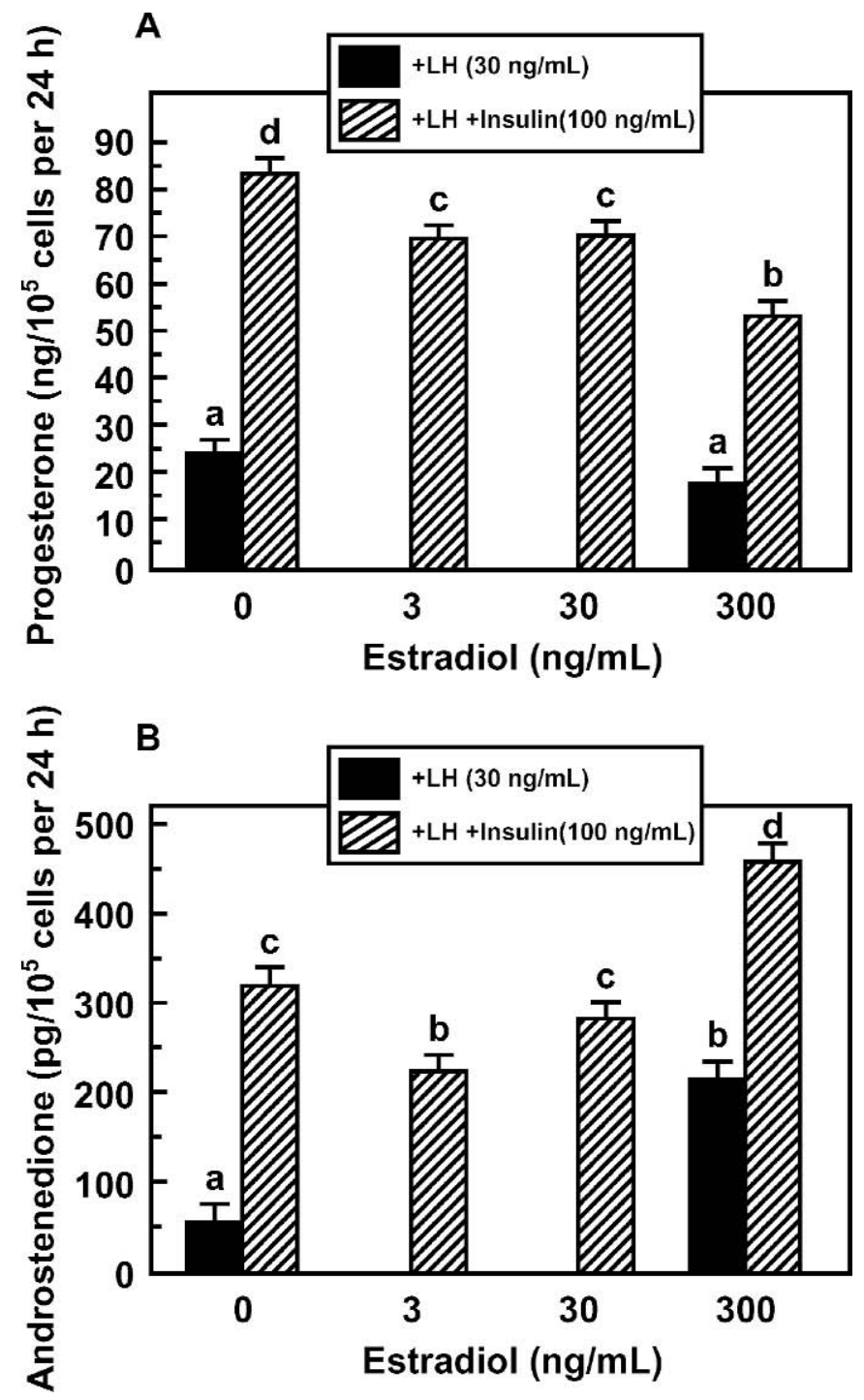

Figure 2. Effect of estradiol (E2) on insulin plus LH-induced progesterone (panel A) and androstenedione (panel B) production by thecal cells from large follicles (experiment 2). Thecal cells were cultured for $4 \mathrm{~d}$ as described in Materials and Methods. During the last $2 \mathrm{~d}$ of culture, cells were treated in serum-free medium with $100 \mathrm{ng} /$ $\mathrm{mL}$ of insulin and $30 \mathrm{ng} / \mathrm{mL}$ of $\mathrm{LH}$ with or without various doses of E2. Values are means from 3 separate experiments. ${ }^{\text {a,b,c,d }}$ Within a panel, means without a common letter differ $(P<0.05)$.

by thecal cells. Specifically, E2 reduced progesterone production by 32 and $26 \%(P<0.05)$ in the presence of 3 and $30 \mathrm{ng} / \mathrm{mL}$ of $\mathrm{LH}$, respectively (Figure $3 \mathrm{~A}$ ).

Androstenedione production. In the presence of insulin $(1000 \mathrm{ng} / \mathrm{mL}), 3$ and $30 \mathrm{ng} / \mathrm{mL}$ of $\mathrm{LH}$ increased $(P<0.05)$ androstenedione production to 5.9- and 9.2fold of controls, respectively (Figure 3B). Estradiol dramatically increased $(P<0.05)$ basal and LH-induced androstenedione production (Figure $3 \mathrm{~B}$ ). 
Table 1. Effect of 2-d treatment of estradiol (E2) in combination with $\mathrm{LH}$, insulin, and IGF-I on numbers of thecal cells from large $(\geq 8 \mathrm{~mm})$ bovine follicles.

\begin{tabular}{|c|c|c|c|c|c|}
\hline \multirow[b]{2}{*}{ Experiment } & \multicolumn{4}{|c|}{ Dose (ng/mL) } & \multirow{2}{*}{$\begin{array}{l}\text { Cell } \\
\text { number } \\
\left(\times 10^{5} \text { per well }\right)\end{array}$} \\
\hline & E2 & $\mathrm{LH}$ & Insulin & IGF-I & \\
\hline \multirow[t]{7}{*}{2} & 0 & 30 & 0 & 0 & $2.28^{\mathrm{a}}$ \\
\hline & 0 & 30 & 100 & 0 & $3.71^{\mathrm{b}}$ \\
\hline & 3 & 30 & 100 & 0 & $3.84^{\mathrm{bc}}$ \\
\hline & 30 & 30 & 100 & 0 & $3.92^{\mathrm{bc}}$ \\
\hline & 300 & 30 & 0 & 0 & $2.24^{\mathrm{a}}$ \\
\hline & 300 & 30 & 100 & 0 & $4.04^{\mathrm{c}}$ \\
\hline & SEM & & & & 0.11 \\
\hline \multirow[t]{7}{*}{4} & 0 & 30 & 0 & 0 & $0.51^{\mathrm{a}}$ \\
\hline & 300 & 30 & 0 & 0 & $0.61^{\mathrm{ab}}$ \\
\hline & 0 & 30 & 0 & 30 & $0.94^{\mathrm{c}}$ \\
\hline & 300 & 30 & 0 & 30 & $0.85^{\mathrm{c}}$ \\
\hline & 0 & 30 & 100 & 0 & $0.90^{\mathrm{c}}$ \\
\hline & 300 & 30 & 100 & 0 & $0.80^{\mathrm{bc}}$ \\
\hline & SEM & & & & 0.08 \\
\hline \multirow[t]{5}{*}{5} & 0 & 0 & 10 & 0 & $1.13^{\mathrm{ab}}$ \\
\hline & 10 & 0 & 10 & 0 & $1.23^{\mathrm{b}}$ \\
\hline & 100 & 0 & 10 & 0 & $1.24^{\mathrm{b}}$ \\
\hline & 1000 & 0 & 10 & 0 & $1.01^{\mathrm{a}}$ \\
\hline & SEM & & & & 0.04 \\
\hline
\end{tabular}

a,b,c Within an experiment, means without a common letter differ $(P<0.05)$

Cell numbers. Neither LH nor E2 affected $(P>0.10)$ cell numbers, which averaged $2.80 \pm 0.06 \times 10^{5}$ cells per well (data not shown).

\section{Experiment 4}

Progesterone production. In the presence of $\mathrm{LH}$, $300 \mathrm{ng} / \mathrm{mL}$ of $\mathrm{E} 2$ decreased $(P<0.05)$ progesterone (Figure $4 \mathrm{~A}$ ) production by $72 \%$. Similarly, E2 decreased $(P$ $<0.05$ ) progesterone production in the presence of IGFI (by 70\%) and insulin (by 77\%) (Figure 4A).

Androstenedione production. In the presence of $\mathrm{LH}, 300 \mathrm{ng} / \mathrm{mL}$ of E2, $30 \mathrm{ng} / \mathrm{mL}$ of IGF-I, and $100 \mathrm{ng} /$ $\mathrm{mL}$ of insulin each increased $(P<0.05)$ androstenedione production to 6.8-, 8.2-, and 6.4-fold of controls, respectively (Figure 4B). Estradiol amplified $(P<0.05)$ the IGF-I- and insulin-induced increase in androstenedione production by 21 and $66 \%$, respectively, but this response was less than additive (Figure 4B).

Cell numbers. Both IGF-I and insulin (but not LH) increased $(P<0.05)$ cell numbers (Table 1$)$. However, $300 \mathrm{ng} / \mathrm{mL}$ of E2 had no effect $(P>0.10)$ on IGF-I- or insulin-induced cell numbers (Table 1).

\section{Experiment 5}

Progesterone production. Dose of E2 $(P<0.01)$ had a biphasic influence on progesterone production by thecal cells (Figure 5A). In the presence of low (10 ng/ $\mathrm{mL}$ ) insulin but absence of $\mathrm{LH}, 10$ and $100 \mathrm{ng} / \mathrm{mL}$ of
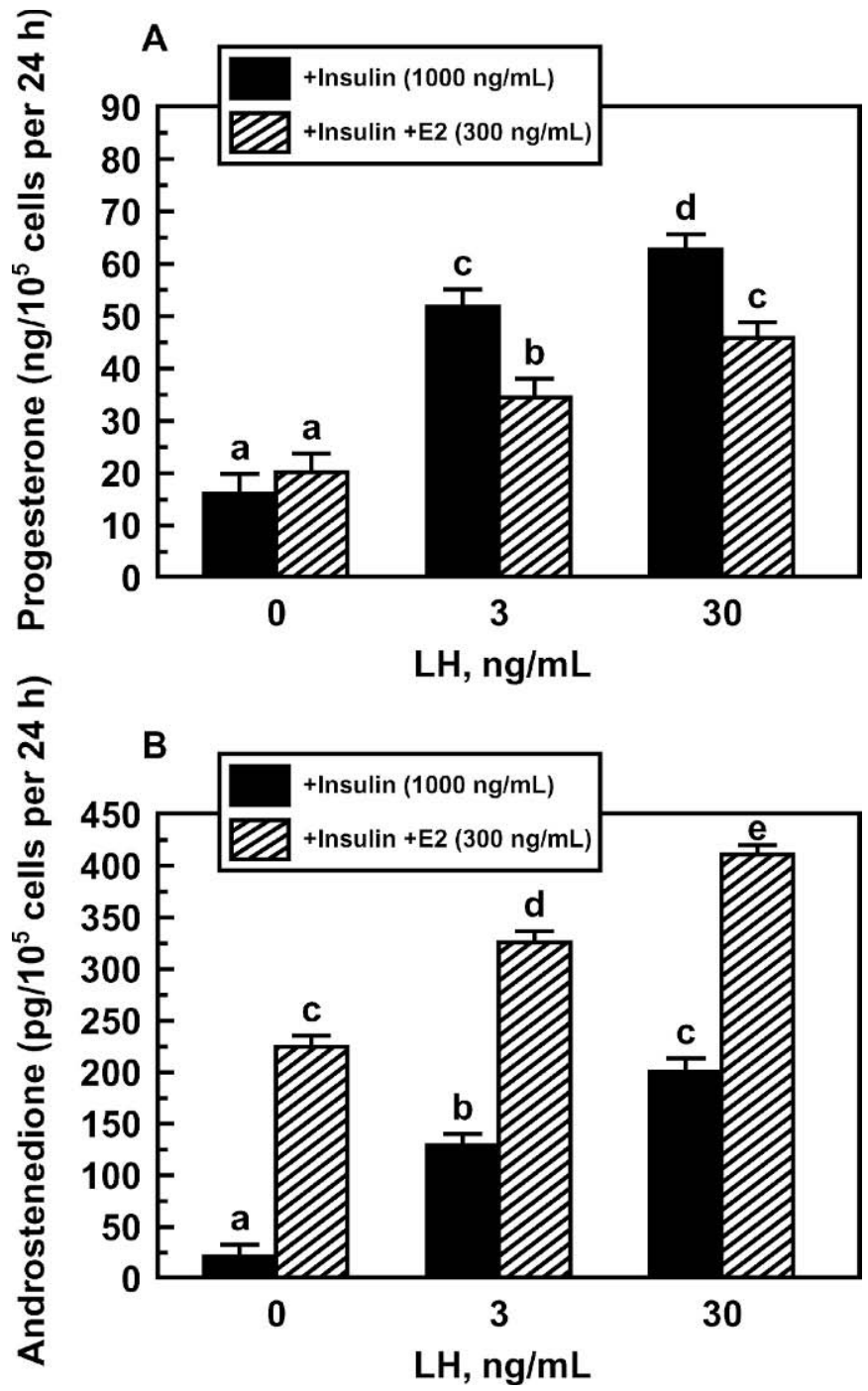

Figure 3. Effect of estradiol (E2) on LH-induced progesterone (panel A) and androstenedione (panel B) production by thecal cells from large follicles (experiment 3). Thecal cells were cultured for 4 $\mathrm{d}$ as described in Materials and Methods. During the last $2 \mathrm{~d}$ of culture, cells were treated in serum-free medium with $1000 \mathrm{ng} / \mathrm{mL}$ of insulin and 0,3 , or $30 \mathrm{ng} / \mathrm{mL}$ of $\mathrm{LH}$ with or without $300 \mathrm{ng} / \mathrm{mL}$ of E2. Values are means from 3 separate experiments. ${ }^{\text {a,b,c,d,e Within a }}$ panel, means without a common letter differ $(P<0.05)$.

E2 increased $(P<0.05)$ progesterone production to $1.3-$ and 1.5-fold, respectively, whereas $1000 \mathrm{ng} / \mathrm{mL}$ of E2 decreased $(P<0.05)$ progesterone production by $49 \%$ (Figure 5A).

$\left[^{125} I\right]-I G F-I$ binding sites. Estradiol had no effect $(P>0.10)$ on the number of $\left[{ }^{125} \mathrm{I}\right]-\mathrm{IGF}-\mathrm{I}$ binding sites (Figure 5B).

Cell numbers. Doses of 10 and $100 \mathrm{ng} / \mathrm{mL}$ of $\mathrm{E} 2 \mathrm{had}$ no effect $(P>0.10)$ on cell numbers, whereas $1000 \mathrm{ng} /$ $\mathrm{mL}$ of $\mathrm{E} 2$ weakly decreased (i.e., $11 \%$ decrease) cell numbers in the presence of $10 \mathrm{ng} / \mathrm{mL}$ of insulin (Table 1). 

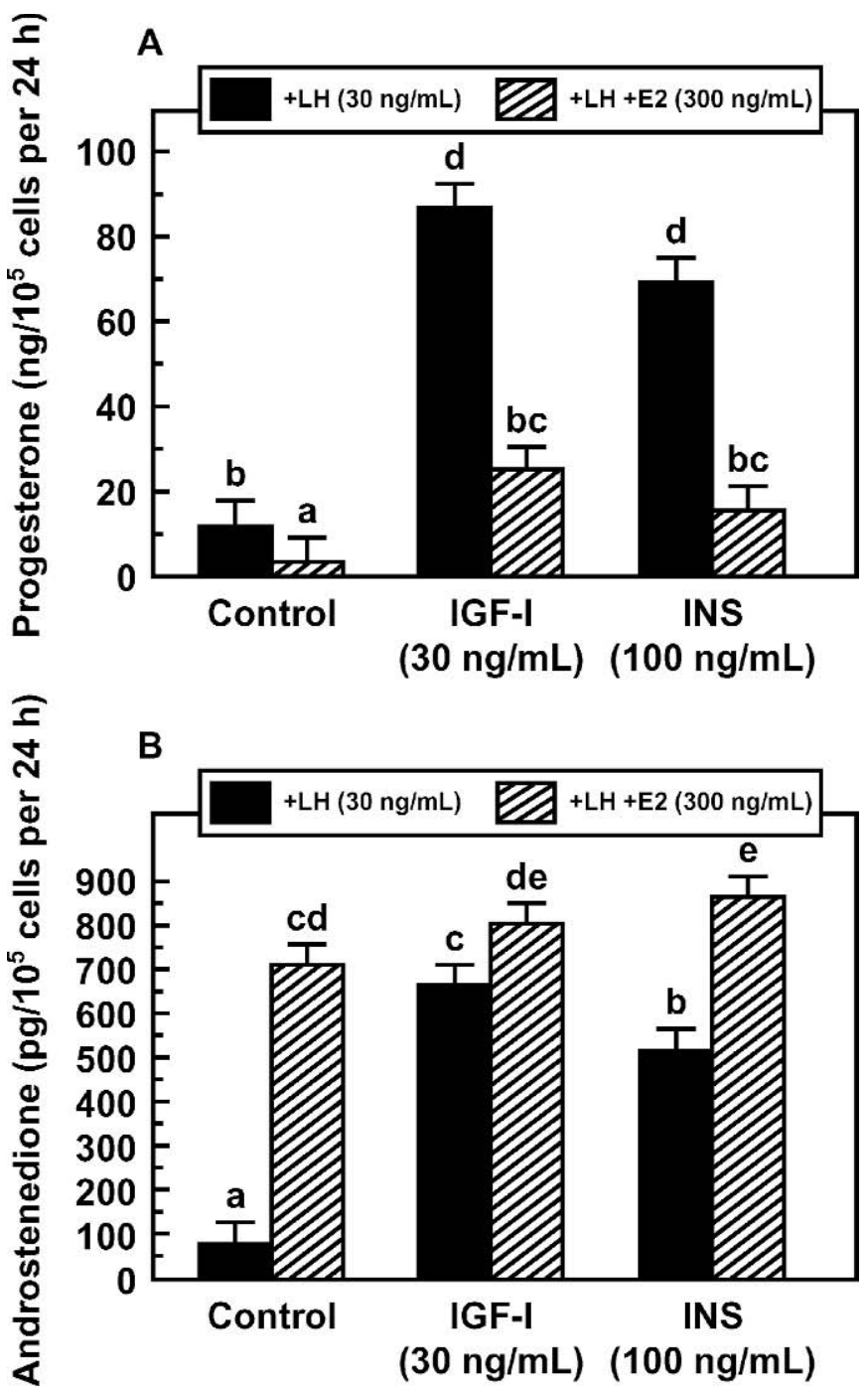

Figure 4. Effect of estradiol (E2) on basal and hormone-induced progesterone (panel A) and androstenedione (panel B) production by thecal cells from large follicles (experiment 4). Thecal cells were cultured for $4 \mathrm{~d}$ as described in Materials and Methods. During the last $2 \mathrm{~d}$ of culture, cells were treated in serum-free medium with 30 $\mathrm{ng} / \mathrm{mL}$ of LH, 0 or $100 \mathrm{ng} / \mathrm{mL}$ of insulin (INS), and 0 or $30 \mathrm{ng} / \mathrm{mL}$ of IGF-I with or without $300 \mathrm{ng} / \mathrm{mL}$ of E2. Values are means from 3 separate experiments. ${ }^{\mathrm{a}, \mathrm{b}, \mathrm{c}, \mathrm{d}, \mathrm{e}}$ Within a panel, means without a common letter differ $(P<0.05)$.

\section{DISCUSSION}

Results of the present study on bovine thecal cells revealed that: 1) E2 by itself (in the absence of $\mathrm{LH}$ ) is a weak stimulator of progesterone production by thecal cells; 2) E2 has potent inhibitory effects on thecal cell progesterone production induced by LH, LH plus insulin, and LH plus IGF-I; 3) E2 has potent stimulatory effects on thecal cell androstenedione production in the absence of other hormones as well as in the presence of LH, LH plus IGF-I, and LH plus insulin; 4) E2 has
A
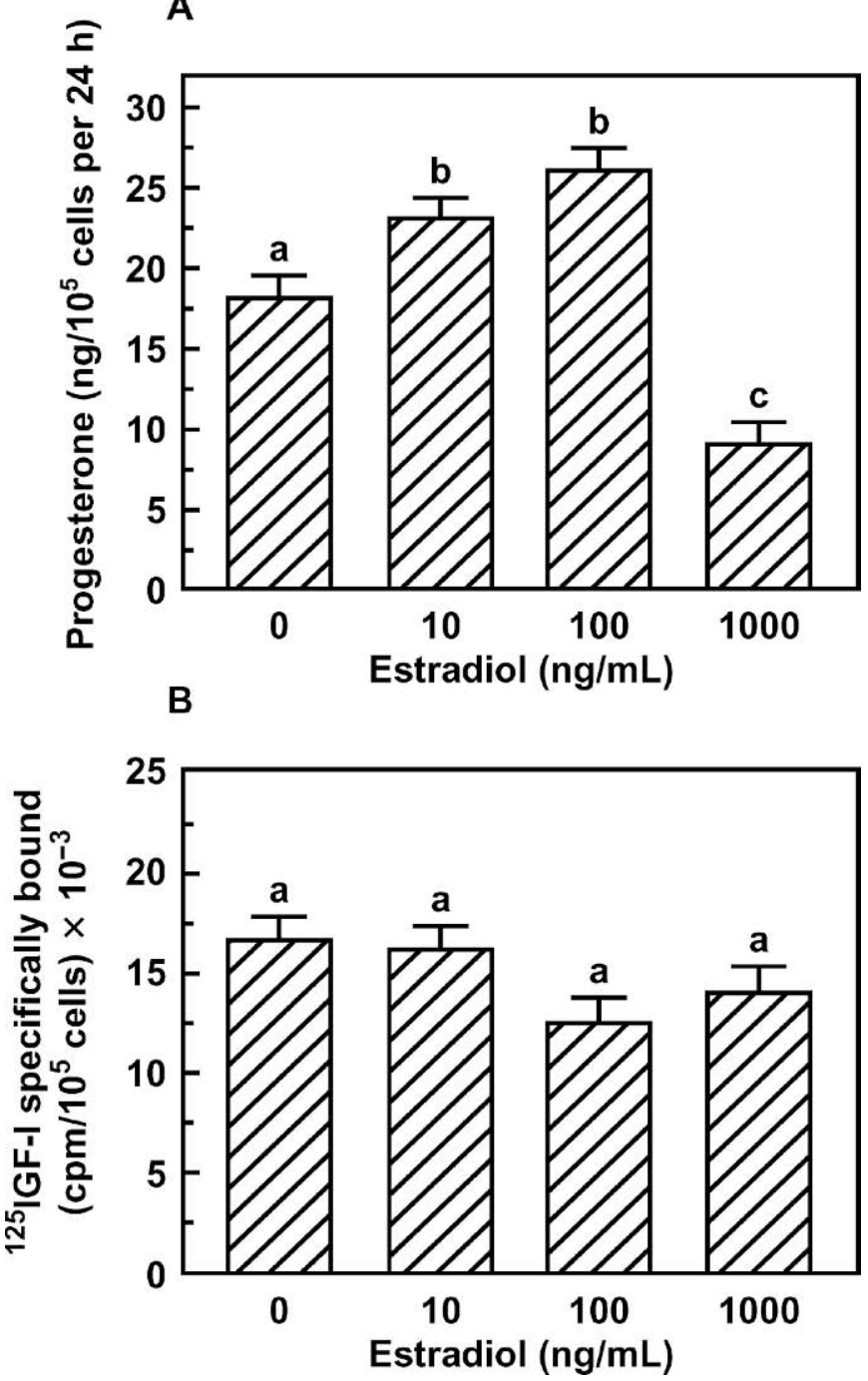

Figure 5. Effect of estradiol (E2) on thecal progesterone production (panel A) and numbers of [ $\left.{ }^{125} \mathrm{I}\right]-\mathrm{IGF}-\mathrm{I}$ binding sites (panel B) (experiment 5). Thecal cells were cultured for $4 \mathrm{~d}$ as described in Materials and Methods. During the last $2 \mathrm{~d}$ of culture, cells were treated in serum-free medium with $10 \mathrm{ng} / \mathrm{mL}$ of insulin with or without the various doses of E2. Values are means from 4 separate experiments. ${ }^{\mathrm{a}, \mathrm{b}, \mathrm{c}}$ Within a panel, means without a common letter differ $(P<0.05)$.

little or no effect on thecal cell numbers; and 5) E2 has no effect on numbers of thecal cell $\left[{ }^{125} \mathrm{I}\right]-\mathrm{IGF}-\mathrm{I}$ binding sites.

Previous studies have suggested that E2 either inhibits (Fortune and Hansel, 1979b; Roberts and Skinner, 1990b; Wrathall and Knight, 1995; Gilling-Smith et al., 1997) or has no effect (Tsang et al., 1979; Morley et al., 1989) on progesterone production induced by $\mathrm{LH}$ in cultured thecal cells. In the present study, we found that $\mathrm{E} 2$ decreased thecal cell progesterone production in the presence of $\mathrm{LH}$ alone or a combination of $\mathrm{LH}$ and insulin or LH and IGF-I. Similar to previous reports, 
LH, insulin, and IGF-I each stimulated progesterone production by bovine thecal cells (Stewart et al., 1995; Spicer and Stewart, 1996a,b; Spicer et al., 1996). In the present study, under basal conditions and in the absence of LH but presence of low $(10 \mathrm{ng} / \mathrm{mL})$ concentrations of insulin, E2 ( 3 to $300 \mathrm{ng} / \mathrm{mL}$ ) had a weak stimulatory effect on progesterone production. In the presence of FCS, $100 \mathrm{ng} / \mathrm{mL}$ to $10 \mu \mathrm{g} / \mathrm{mL}$ of E2 inhibited, whereas 1 and $10 \mathrm{ng} / \mathrm{mL}$ of E2 stimulated LH-induced progesterone production by bovine thecal cells (Fortune and Hansel, 1979a,b). Similarly, in serum-free medium, $1 \mu M$ (i.e., $272 \mathrm{ng} / \mathrm{mL}$ ) of E2 inhibited (by 40 to $50 \%$ ) basal (Roberts and Skinner, 1990a) and human chorionic gonadotropin- (hCG-) induced (Roberts and Skinner, $1990 \mathrm{~b})$ progesterone production by bovine thecal cells. In rat thecal cells cultured with $\mathrm{LH},>500 \mathrm{ng} / \mathrm{mL}$ of E2 had no effect on progesterone production but inhibited $17 \alpha$-hydroxyprogesterone accumulation (Magoffin and Erickson, 1982). In porcine thecal cells, E2 decreased basal and LH-stimulated $17 \alpha$-hydroxyprogesterone accumulations without affecting progesterone production (Morley et al., 1989), and caused a sustained (2 to 4 d) inhibition of hCG-induced progesterone production (Tonetta et al., 1986). Discrepancies among studies could be due to species differences or differences in culture conditions (e.g., duration of treatment and presence or absence of FCS, insulin, and LH). The normal range of average $\mathrm{E} 2$ concentrations in follicular fluid of dairy cattle is from $<1$ to $1500 \mathrm{ng} / \mathrm{mL}$ (Fortune and Hansel, 1979a; Badinga et al., 1992; Stewart et al., 1996; Spicer et al., 2001b). Thus, results of the present and previous studies indicate that at concentrations that mimic intrafollicular levels, E2 may play a major role in the regulation of steroid production by bovine follicles.

Previous studies with bovine (Fortune and Hansel, 1979a; Langhout et al., 1991) and porcine (Veldhuis et al., 1982; Veldhuis, 1985) granulosa cells have also demonstrated species differences in the effect of E2 on steroidogenesis. Specifically, in bovine granulosa cells, E2 inhibits FCS- (Fortune and Hansel, 1979a) and insulin-induced (Langhout et al., 1991) progesterone production. In porcine granulosa cells, E2 enhances basal and gonadotropin-stimulated progesterone production under serum-free (Veldhuis et al., 1984; Veldhuis, 1985; Spicer and Hammond, 1987) and serum-containing (Veldhuis et al., 1982) conditions, but E2 also exhibits biphasic effects on progesterone production (Veldhuis et al., 1981). In particular, this biphasic effect of $\mathrm{E} 2$ on progesterone biosynthesis by porcine granulosa cells causes an initial (12 to $24 \mathrm{~h}$ ) transient inhibition followed by a delayed but sustained ( 2 to $6 \mathrm{~d}$ ) stimulation (Veldhuis et al., 1981; Hunter and Armstrong, 1987). The mechanism of action of $\mathrm{E} 2$ on progesterone produc- tion by porcine granulosa cells appears to be a direct effect on side-chain cleavage enzyme (Veldhuis et al., 1982; Veldhuis, 1985) and $3 \beta$-hydroxysteroid dehydrogenase altering conversion of pregnenolone to progesterone (Veldhuis, 1985). Whether this is the point of E2 inhibition on progesterone production by bovine thecal cells in the present study will require further study. Moreover, depletion of putative endogenous pools of progestins and their precursors that are used for androgen production (see next section) could have in part accounted for the decrease in progesterone production caused by $\mathrm{E} 2$, but further research will be needed to verify this suggestion.

A stimulatory effect of $\mathrm{E} 2$ on androstenedione production has been previously reported for bovine (Roberts and Skinner, 1990a,b; Wrathall and Knight, 1995), human (Gilling-Smith et al., 1997), and porcine (Tsang et al., 1979; Morley et al., 1989) thecal cells, and is confirmed by the present study. We further extend these previous findings, showing that E2 can dramatically enhance basal and LH-induced androstenedione production as well as amplifying insulin-, LH plus insulin-, and LH plus IGF-I-induced androstenedione production. The less than additive androstenedione responses of thecal cells to combined treatments of $\mathrm{E} 2$ and insulin or E2 and IGF-I indicate that these hormones may share a common or overlapping intracellular pathway. Alternatively, the 2-d stimulation of thecal cell androstenedione production by $\mathrm{E} 2$ may have resulted in depletion of the cholesterol and progestin precursors available for maximal androstenedione production. Thus, the present and previous studies indicate that the inhibitory effect of $\mathrm{E} 2$ on progesterone production by bovine thecal cells may be due in part to stimulation of the enzymes that convert progestins into androgens (i.e., stimulation of 17,20 lyase or $17 \alpha$ hydroxylase). Because bovine thecal cells preferentially use the $\Delta^{5}$ pathway (Lacroix et al., 1974; Fortune, 1986), inhibition of progesterone production by E2 could promote androgen synthesis via the $\Delta^{5}$-pathway. However, in rats, estrogens inhibit androgen production by thecal cells and inhibit $17 \alpha$-hydroxyprogesterone accumulation (Magoffin and Erickson, 1981, 1982; Johnson and Crane, 1995) suggesting that E2 inhibits production of important androgen precursors in this species (Liu and Hsueh, 1986). Further research will be needed to identify any shared or overlapping component(s) of the intracellular mechanism by which E2, LH, IGF-I, and insulin stimulate androstenedione production in bovine thecal cells.

No consistent effect of E2 was observed on thecal cell numbers in the present study. Previously, 40-h treatment with estradiol (10 to $1000 \mathrm{ng} / \mathrm{mL}$ ) has been shown to decrease DNA synthesis (by 20 to 50\%) as measured 
by $\left[{ }^{3} \mathrm{H}\right]$-thymidine incorporation in porcine thecal (Ranson et al., 1997) and granulosa cells (Spicer and Hammond, 1989). Whether the difference between the present and previous studies is due to species differences, duration of treatment, or both will require further study. In nonlactating cows, long-term (i.e., 75 d) E2 treatment increases the number of corpora lutea formed after superovulation in nonlactating cows (Cushman et al., 2001a) and increases percentages of primary follicles (Cushman et al., 2001b). Furthermore, in vitro treatment of bovine preantral follicles with E2 for $7 \mathrm{~d}$ decreased numbers of granulosa cells but did not alter their proliferative activity (Hulshof et al., 1995). Thus, additional research will be needed to determine whether E2 directly alters follicle growth in cattle via action on granulosa cells, thecal cells, or both.

In the present study, the mechanism of action of E2 on IGF-I-stimulated progesterone and androstenedione production by bovine thecal cells did not appear to involve a change in IGF type I receptors. In contrast, E2 increases IGF type I receptors in porcine (Veldhuis et al., 1986) and bovine (Spicer et al., 1994) granulosa cells. Thus, differences between granulosa and thecal cells may exist in terms of the mechanism of action of E2 regulating hormone-induced steroidogenesis. This difference in the granulosa and thecal cell responses may be due to differences in the type (i.e., $\alpha$ or $\beta$ ) of estrogen receptor present in granulosa vs. thecal cells, and may prove to be one of the keys to understanding differential E2 responses in these 2 cell types. Previous studies have localized $\mathrm{ER} \alpha$ mainly to thecal cells and $\mathrm{ER} \beta$ mainly to granulosa cells in rat (Sar and Welsch, 1999; Pelletier et al., 2000; Berisha et al., 2002) and bovine (Rosenfeld et al., 1999; Berisha et al., 2002) follicles. In humans, $\mathrm{ER} \alpha$ and $\mathrm{ER} \beta$ are expressed in both granulosa and thecal cells (Saunders et al., 2000; Wang et al., 2000; Jakimiuk et al., 2002). Moreover, estrogen receptors appear to be regulated by hormones because in vivo treatment with hCG/LH dramatically decreases specific $\left[{ }^{3} \mathrm{H}\right]$-E2 binding to rat granulosa cells (Richards, $1975)$ and $\operatorname{ER} \beta$ mRNA levels in mouse granulosa cells (Byers et al., 1997; Fitzpatrick et al., 1999). Levels of $\mathrm{ER} \alpha$ and $\mathrm{ER} \beta$ mRNA in thecal and granulosa cells also increase with increased follicular size (Manikkam et al., 2001), and follicular E2 levels in cattle (Berisha et al., 2002) and specific binding of $\left[{ }^{3} \mathrm{H}\right]-\mathrm{E} 2$ to rat granulosa cells are increased by E2 treatment in vivo (Richards, 1975). Whether the various hormones used in the present study altered amounts of $\operatorname{ER} \alpha$ or $\operatorname{ER} \beta$ in thecal cells will require further elucidation.

\section{CONCLUSIONS}

In conclusion, the present study provides further supportive evidence for a paracrine role of $\mathrm{E} 2$ in regulating steroidogenesis of bovine follicles. Our studies indicate that E2 may have a major positive impact on basal, LH-, IGF-I-, and insulin-induced androstenedione production by bovine thecal cells, which could further increase estrogen production by the follicle. Thus, these results support the hypothesis that E2 synthesized within the follicle is part of a paracrine positive feedback system that acts to promote E2 production by the dominant follicle in cattle via increased androstenedione production. Future studies should focus on evaluating the effect of $\mathrm{E} 2$ in vivo, so that ultimately, the impact of $\mathrm{E} 2$ on reproductive efficiency of dairy cattle can be ascertained.

\section{ACKNOWLEDGMENTS}

The author thanks C. Francisco, C. Chamberlain, and D. Allen for technical assistance; Paula Cinnamon for secretarial assistance; and Wellington Quality Meats (Wellington, KS) and Mikkelson Beef, Inc. (Oklahoma City, OK) for their generous donations of bovine ovaries.

\section{REFERENCES}

Badinga, L., M. A. Driancourt, J. D. Savio, D. Wolfenson, M. Drost, R. L. de la Sota, and W. W. Thatcher. 1992. Endocrine and ovarian responses associated with the first-wave dominant follicle in cattle. Biol. Reprod. 47:871-883.

Bao, B., N. Kumar, R. M. Karp, H. A. Garverick, and K. Sundaram. 2000 . Estrogen receptor- $\beta$ expression in relation to the expression of luteinizing hormone receptor and cytochrome P450 enzymes in rat ovarian follicles. Biol. Reprod. 63:1747-1755.

Beam, S. W., and W. R. Butler. 1998. Energy balance, metabolic hormones, and early postpartum follicular development in dairy cows fed prilled lipid. J. Dairy Sci. 81:121-131.

Berisha, B., M. W. Pfaffl, and D. Schams. 2002. Expression of estrogen and progesterone receptors in the bovine ovary during estrous cycle and pregnancy. Endocrine 17:207-214.

Brandenberger, A. W., M. K. Tee, and R. B. Jaffe. 1998. Estrogen receptor alpha (ER- $\alpha)$ and beta (ER- $\beta$ ) mRNAs in normal ovary, ovarian serous cystadenocarcinoma and ovarian cancer cell lines: Down-regulation of ER- $\beta$ in neoplastic tissues. J. Clin. Endocrinol. Metab. 83:1025-1028.

Buhi, W. C. 2002. Characterization and biological roles of oviductspecific, oestrogen-dependent glycoprotein. Reproduction 123:355-362.

Byers, M., G. G. Kuiper, J. A. Gustafsson, and O. K. Park-Sarge. 1997. Estrogen receptor- $\beta$ mRNA expression in rat ovary: Downregulation by gonadotropins. Mol. Endocrinol. 11:172-182.

Couse, J. F., D. O. Bunch, J. Lindzey, D. W. Schomberg, and K. S. Korach. 1999. Prevention of the polycystic ovarian phenotype and characterization of ovulatory capacity in the estrogen receptor- $\alpha$ knockout mouse. Endocrinology 140:5855-5865.

Cushman, R. A., J. C. DeSouza, V. S. Hedgpeth, and J. H. Britt. 2001a. Effect of long-term treatment with recombinant bovine somatotropin and estradiol on hormone concentrations and ovulatory response of superovulated cattle. Theriogenology 55:15331547.

Cushman, R. A., J. C. DeSouza, V. S. Hedgpeth, and J. H. Britt. $2001 \mathrm{~b}$. Alteration of activation, growth, and atresia of bovine preantral follicles by long-term treatment of cows with estradiol and recombinant bovine somatotropin. Biol. Reprod. 65:581-586.

Fitzpatrick, S. L., J. M. Funkhouser, D. M. Sindoni, P. E. Stevis, D. C. Deecher, A. R. Bapat, I. Merchenthaler, and D. E. Frail. 1999. 
Expression of estrogen receptor- $\beta$ protein in rodent ovary. Endocrinology 140:2581-2591.

Fortune, J. E. 1986. Bovine theca and granulosa cells interact to promote androgen production. Biol. Reprod. 35:292-299.

Fortune, J. E., and W. Hansel. 1979a. The effects of $17 \beta$-estradiol on progesterone secretion by bovine theca and granulosa cells. Endocrinology 104:1834-1838.

Fortune, J. E., and W. Hansel. 1979b. Modulation of thecal progesterone secretion by estradiol-17 $\beta$. Adv. Exp. Med. Biol. 112:203-208.

Gilling-Smith, C., D. S. Willis, and S. Franks. 1997. Oestradiol feedback stimulation of androgen biosynthesis by human thecal cells. Hum. Reprod. 12:1621-1628.

Hulshof, S. C. J., J. R. Figueiredo, J. F. Beckers, M. M. Bevers, J. A. van der Donk, and R. van den Hurk. 1995. Effects of fetal bovine serum, FSH and $17 \beta$-estradiol on the culture of bovine preantral follicles. Theriogenology 44:217-226.

Hunter, M. G., and D. T. Armstrong. 1987. Oestrogens inhibit steroid production by dispersed porcine thecal cells. Mol. Cell. Endocrinol. 50:165-170.

Jakimiuk, A. J., S. R. Weitsman, H.-W. Yen, M. Bogusiewicz, and D. A. Magoffin. 2002. Estrogen receptor $\alpha$ and $\beta$ expression in theca and granulosa cells from women with polycystic ovary syndrome. J. Clin. Endocrinol. Metab. 87:5532-5538.

Johnson, D. C., and L. H. Crane. 1995. Inhibitory and stimulatory effect of oestrogens upon ovarian $17 \alpha$-hydroxylase/C17, 20-lyase in immature hypophysectomized rats treated with gonadotropin. J. Endocrinol. 145:59-67.

Lacroix, E., W. Eechaute, and I. Leusen. 1974. The biosynthesis of estrogens by cow follicles. Steroids 23:337-356.

Langhout, D. J., L. J. Spicer, and R. D. Geisert. 1991. Development of a culture system for bovine granulosa cells: Effects of growth hormone, estradiol and gonadotropins on cell proliferation, steroidogenesis and protein synthesis. J. Anim. Sci. 69:3321-3334.

Liu, Y. X., and A. J. Hsueh. 1986. Synergism between granulosa and theca-interstitial cells in estrogen biosynthesis by gonadotropintreated rat ovaries: Studies on the two-cell, two-gonadotropin hypothesis using steroid antisera. Biol. Reprod. 35:27-36.

Magoffin, D. A., and G. F. Erickson. 1981. Mechanism by which $17 \beta$ estradiol inhibits ovarian androgen production in the rat. Endocrinology 108:962-969.

Magoffin, D. A., and G. F. Erickson. 1982. Direct inhibitory effect of estrogen on LH-stimulated androgen synthesis by ovarian cells cultured in defined medium. Mol. Cell. Endocrinol. 28:81-89.

Manikkam, M., B. Bao, C. S. Rosenfeld, X. Yuan, B. E. Salfen, M. D. Calder, R. S. Youngquist, D. H. Keisler, D. B. Lubahn, and H. A. Garverick. 2001. Expression of the bovine oestrogen receptor$\beta(\mathrm{bER} \beta)$ messenger ribonucleic acid (mRNA) during the first ovarian follicular wave and lack of change in the expression of bER $\beta$ mRNA of second wave follicles after LH infusion into cows. Anim. Reprod. Sci. 67:159-169.

Morley, P., M. W. Khalil, F. R. Calaresu, and D. T. Armstrong. 1989. Catecholestrogens inhibit basal and luteinizing hormone-stimulated androgen production by porcine thecal cells. Biol. Reprod. 41:446-453.

Orikasa, C., and Y. Sakuma. 2003. Possible involvement of preoptic estrogen receptor $\beta$ positive cells in luteinzing hormone surge in the rat. Domest. Anim. Endocrinol. 25:83-92.

Ott, L. 1977. Pages 384-388 in An Introduction to Statistical Methods and Data Analysis. Duxbury Press, North Scituate, MA.

Pelletier, G., C. Labrie, and F. Labrie. 2000. Localization of oestrogen receptor $\alpha$, oestrogen receptor $\beta$ and androgen receptors in the rat reproductive organs. J. Endocrinol. 165:359-370.

Ranson, E. J., H. M. Picton, and M. G. Hunter. 1997. Effects of testosterone and oestradiol on $\left[{ }^{3} \mathrm{H}\right]$-thymidine incorporation by porcine granulosa and theca cells. Anim. Reprod. Sci. 47:229-236.

Richards, J. S. 1975. Estradiol receptor content in rat granulosa cells during follicular development: Modification by estradiol and gonadotropins. Endocrinology 97:1174-1184.

Richards, J. S., J. J. Ireland, M. C. Rao, G. A. Bernath, A. R. Midgley, Jr., and L. E. Reichert, Jr. 1976. Ovarian follicular development in the rat: Hormone receptor regulation by estradiol, follicle stim- ulating hormone and luteinizing hormone. Endocrinology 99:1562-1570.

Roberts, A. J., and M. K. Skinner. 1990a. Estrogen regulation of thecal cell steroidogenesis and differentiation: Thecal cell-granulosa cell interactions. Endocrinology 127:2918-2929.

Roberts, A. J., and M. K. Skinner. 1990b. Mesenchymal-epithelial cell interactions in the ovary: Estrogen-induced theca cell steroidogenesis. Mol. Cell. Endocrinol. 72:R1-R5.

Rosenfeld, C. S., X. Yuan, M. Manikkam, M. D. Calder, H. A. Garverick, and D. B. Lubahn. 1999. Cloning, sequencing, and localization of bovine estrogen receptor- $\beta$ within the ovarian follicle. Biol. Reprod. 60:691-697.

Sar, M., and F. Welsch. 1999. Differential expression of estrogen receptor- $\beta$ and estrogen receptor- $\alpha$ in the rat ovary. Endocrinology 140:963-971.

SAS Institute. 1999. The SAS system for Windows: Version 8. SAS Institute, Inc., Cary, NC.

Saunders, P. T. K., M. R. Millar, K. Williams, S. Macpherson, D. Harkiss, R. A. Anderson, B. Orr, N. P. Groome, G. Scobie, and H. M. Fraser. 2000. Differential expression of estrogen receptor$\alpha$ and $-\beta$ and androgen receptor in the ovaries of marmosets and humans. Biol. Reprod. 63:1098-1105.

Sharma, S. C., J. W. Clemens, M. D. Pisarska, and J. S. Richards. 1999. Expression and function of estrogen receptor subtypes in granulosa cells: Regulation by estradiol and forskolin. Endocrinology 140:4320-4334.

Slomczynska, M., and J. Wozniak. 2001. Differential distribution of estrogen receptor- $\beta$ and estrogen receptor- $\alpha$ in the porcine ovary. Exp. Clin. Endocrinol. Diabetes 109:238-244.

Spicer, L. J. 2001. Receptors for insulin-like growth factor-I and tumor necrosis factor- $\alpha$ are hormonally regulated in bovine granulosa and thecal cells. Anim. Reprod. Sci. 67:45-58.

Spicer, L. J., J. Alonso, and C. S. Chamberlain. 2001a. Effects of thyroid hormones on bovine granulosa and thecal cell function in vitro: Dependence on insulin and gonadotropins. J. Dairy Sci. 84:1069-1076.

Spicer, L. J., E. Alpizar, and R. K. Vernon. 1994. Insulin-like growth factor-I receptors in ovarian granulosa cells: Effect of follicle size and hormones. Mol. Cell. Endocrinol. 102:69-76.

Spicer, L. J., and C. S. Chamberlain. 1998. Influence of cortisol on insulin and insulin-like growth factor I (IGF-I)-induced steroid production and on IGF-I receptors in cultured bovine granulosa cells and thecal cells. Endocrine 9:153-161.

Spicer, L. J., C. S. Chamberlain, and G. L. Morgan. 2001b. Proteolysis of insulin-like growth factor binding proteins during preovulatory follicular development in cattle. Domest. Anim. Endocrinol. 21:1-15.

Spicer, L. J., E. M. Convey, K. Leung, R. E. Short, and H. A. Tucker. 1986a. Anovulation in postpartum suckled beef cows. II. Associations among binding of ${ }^{125}$ I-labeled gonadotropins to granulosa and thecal cells, and concentrations of steroids in serum and various sized ovarian follicles. J. Anim. Sci. 62:742-750.

Spicer, L. J., E. M. Convey, H. A. Tucker, and S. E. Echternkamp. 1986b. Effects of intermittent injections of LHRH on specific binding of ${ }^{125}$ I-labeled gonadotropins to granulosa and theca, and concentrations of steroids in serum and ovarian follicles during postpartum anovulation in suckled beef cows. J. Anim. Sci. 62:1324-1331.

Spicer, L. J., and S. E. Echternkamp. 1986. Ovarian follicular growth, function and turnover in cattle: A review. J. Anim. Sci. 62:428-451.

Spicer, L. J., T. D. Hamilton, and B. E. Keefer. 1996. Insulin-like growth factor I enhancement of steroidogenesis by bovine granulosa cells and thecal cells: Dependence on de novo cholesterol synthesis. J. Endocrinol. 151:365-373.

Spicer, L. J., and J. M. Hammond. 1987. Catecholestrogens stimulate progestin secretion by cultured porcine granulosa cells. Mol. Cell. Endocrinol. 50:139-147.

Spicer, L. J., and J. M. Hammond. 1989. Catecholestrogens inhibit proliferation and DNA synthesis of porcine granulosa cells in vitro: Comparison with estradiol, $5 \alpha$-dihydrotestosterone, gonadotropins and catecholamines. Mol. Cell. Endocrinol. 64:119-126. 
Spicer, L. J., P. Matton, S. E. Echternkamp, E. M. Convey, and H. A. Tucker. 1987. Relationships between histological signs of atresia, steroids in follicular fluid, and gonadotropin binding in individual bovine antral follicles during postpartum anovulation. Biol. Reprod. 36:890-898.

Spicer, L. J., and R. E. Stewart. 1996a. Interaction among bovine somatotropin, insulin and gonadotropins on steroid production by bovine granulosa and thecal cells. J. Dairy Sci. 79:813-821.

Spicer, L. J., and R. E. Stewart. 1996b. Interactions among basic fibroblast growth factor, epidermal growth factor, insulin, and insulin-like growth factor-I (IGF-I) on cell numbers and steroidogenesis of bovine thecal cells: Role of IGF-I receptors. Biol. Reprod. $54: 255-263$.

Stewart, R. E., L. J. Spicer, T. D. Hamilton, and B. Keefer. 1995. Effect of insulin-like growth factor-I and insulin on proliferation and on luteinizing hormone-induced-steroidogenesis of bovine theca cells: Involvement of glucose and receptors for insulin-like growth factor I and luteinizing hormone. J. Anim. Sci. 73:3719-3731

Stewart, R. E., L. J. Spicer, T. D. Hamilton, B. E. Keefer, L. J. Dawson, G. L. Morgan, and S. E. Echternkamp. 1996. Levels of insulinlike growth factor (IGF) binding proteins, luteinizing hormone and IGF-I receptors, and steroids in dominant follicles during the first follicular wave in cattle exhibiting regular estrous cycles. Endocrinology 137:2842-2850.

Tonetta, S. A., R. S. DeVinna, and G. S. diZerega. 1986. Modulation of porcine thecal cell aromatase activity by human chorionic gonadotropin, progesterone, estradiol-17 $\beta$, and dihydrotestosterone. Biol. Reprod. 35:785-791.

Tonetta, S. A., L. J. Spicer, and J. J. Ireland. 1985. CI628 inhibits follicle-stimulating hormone (FSH)-induced increases in FSH receptors of the rat ovary: Requirement of estradiol for FSH action. Endocrinology 116:715-722.

Tsang, B. K., P. C. Leung, and D. T. Armstrong. 1979. Inhibition by estradiol-17 $\beta$ of porcine thecal androgen production in vitro. Mol. Cell. Endocrinol. 14:131-139.

Van Den Broeck, W., M. Coryn, P. Simoens, and H. Lauwers. 2002. Cell-specific distribution of oestrogen receptor- $\alpha$ in the bovine ovary. Reprod. Domest. Anim. 37:291-293.
Veldhuis, J. D. 1985. Bipotential actions of estrogen on progesterone biosynthesis by ovarian cells. II. Relation of estradiol's stimulatory actions to cholesterol and progestin metabolism in cultured swine granulosa cells. Endocrinology 117:1076-1083.

Veldhuis, J. D., J. T. Gwynne, J. F. Strauss, III, and L. M. Demers. 1984. Role of estradiol as a biological amplifier of gonadotropin action in the ovary: In vitro studies using swine granulosa cells and homologous lipoproteins. Endocrinology 114:2312-2322.

Veldhuis, J. D., P. A. Klase, and J. M. Hammond. 1981. Direct actions of $17 \beta$-estradiol on progesterone production by highly differentiated porcine granulosa cells in vitro. II. Regulatory interactions of estradiol with luteinizing hormone and cyclic nucleotides. Endocrinology 109:433-442.

Veldhuis, J. D., P. A. Klase, J. F. Strauss, III, and J. M. Hammond. 1982. The role of estradiol as a biological amplifier of the actions of follicle-stimulating hormone: In vitro studies in swine granulosa cells. Endocrinology 111:144-151.

Veldhuis, J. D., R. J. Rodgers, and R. W. Furlanetto. 1986. Synergistic actions of estradiol and the insulin-like growth factor somatomedin-C on swine ovarian (granulosa) cells. Endocrinology 119:530-538.

Voge, J. L., C. A. Santiago, P. Y. Aad, D. W. Goad, J. R. Malayer, and L. J. Spicer. 2004. Quantification of insulin-like growth factor binding protein mRNA using real-time PCR in bovine granulosa and theca cells: Effect of estradiol, insulin, and gonadotropins. Domest. Anim. Endocrinol. 26:241-258.

Wang, H., H. Eriksson, and L. Sahlin. 2000. Estrogen receptors a and $\beta$ in the female reproductive tract of the rat during the estrous cycle. Biol. Reprod. 63:1331-1340.

Wilson, S. J., R. S. Marion, J. N. Spain, D. E. Spiers, D. H. Keisler, and M. C. Lucy. 1998. Effects of controlled heat stress on ovarian function of dairy cattle. 1. Lactating cows. J. Dairy Sci. 81:2124-2131

Wolfenson, D., B. J. Lew, W. W. Thatcher, Y. Graber, and R. Meidan. 1997. Seasonal and acute heat stress effects on steroid production by dominant follicles in cows. Anim. Reprod. Sci. 47:9-19.

Wrathall, J. H. M., and P. G. Knight. 1995. Effects of inhibin-related peptides and oestradiol on androstenedione and progesterone secretion by bovine theca cells in vitro. J. Endocrinol. 145:491-500. 